\title{
Flora of Espírito Santo, Brazil \\ Flora of Espírito Santo, Brazil: Alismataceae
}

\author{
Lígia Queiroz Matias $^{1,2,4}$ \& Hugo Pereira do Nascimento ${ }^{1,3}$
}

\begin{abstract}
This floristic survey of Alismataceae from the state of Espírito Santo aims to update the diversity and extinction vulnerability data for the species. The taxa here listed were obtained from Splink and Reflora Virtual Herbarium databases. A total of seven native taxa were registered for Espírito Santo state: Echinodorus grandiflorus, E. macrophyllus, Helanthium bolivianus, Hydrocleis nymphoides, Limnocharis flava, Sagittaria lancifolia and S. rhombifolia; the exotic species Alisma plantago-aquatica presented one single record. The populations occurred in flooded areas located at low altitudes and were primarily collected from some preserved areas and in the coastal region of the state. This study presents a taxonomic identification key, morphological descriptions and species illustrations. Comments on ecology, conservation and geographical distribution of the species are also presented.
\end{abstract}

Key words: Alismatales, aquatic plants, wetlands.

\section{Resumo}

O levantamento florístico de Alismataceae do estado do Espírito Santo objetivou a atualização dos dados de diversidade e de vulnerabilidade à extinção das espécies. Os táxons aqui listados foram obtidos dos bancos de dados do Splink e do Herbarium Virtual Reflora. Um total de sete táxons nativos foi registrado para o estado do Espírito Santo: Echinodorus grandiflorus, E. macrophyllus, Helanthium bolivianus, Hydrocleis nymphoides, Limnocharis flava, Sagittaria lancifolia e S. rhombifolia; uma espécie exótica, Alisma plantago-aquatica, apresentou um registro pontual. As populações ocorrem em áreas alagadas situadas em altitudes baixas, cujas coletas foram concentradas em algumas áreas preservadas e na região litorânea do estado. Este estudo apresenta uma chave de identificação dos táxons, descrições morfológicas e ilustrações das espécies. Comentários sobre a ecologia, conservação e distribuição das espécies também são apresentados.

Palavras-chave: Alismatales, plantas aquáticas, áreas alagadas.

\section{Introduction}

Humid forests are the predominant native formations in Espírito Santo state, with landscapes that are only altered by pioneer and psamophilous herbaceous-shrub formations found in the coastal regions, by high altitude fields (above 1,500 m) with lithic soils, and by savanna enclaves in the northern region of the state (Garbin et al. 2017).
The wetlands that permeate forest formations are characterized by the presence of large perennial rivers and their respective lake systems, which to extend to the coast (Jordy Filho 1987).

Floristic inventories of swamps and lagoons of the coastal region in Espirito Santo state (Valadares et al. 2011; Souza et al. 2017) reported 182 Angiosperm species. However, only two

\footnotetext{
${ }^{1}$ Universidade Federal Ceará, Centro de Ciências, Depto. Biologia, Lab. Taxonomia de Angiospermas, Campus do Pici, Fortaleza, CE, Brasil.

${ }^{2}$ ORCID: <https://orcid.org/0000-0002-1889-5354>.

${ }^{3}$ ORCID: < https://orcid.org/0000-0003-0995-3193>.

${ }^{4}$ Author for correspondence: lqmatias@ufc.br
} 
species of Alimataceae were recorded in these studies. The richness of Alismataceae species found in geographically similar state in Brazil where Atlantic Forest is the core vegetation, i.e. Rio de Janeiro state, with a total of nine species have been recorded (Canalli \& Bove 2017). In other state with marked seasonality, i.e., Ceará state, 13 species have been recorded (Matias \& Sousa 2011). Although, Flora do Brasil Online reports 6 species of Alismataceae for Espirito Santo, the number of species reported to Espírito Santo could be indicate that the richness of Alismataceae are underestimated.

Considering that Brazil presents 37 species distributed in five genera (Matias 2020), describing the flora of Espírito Santo state will update floristic data and help to evaluate the need for conservation initiatives for species with restricted distribution in the state or vulnerable to environmental change. The biological data associated with the species list provides basic information for scientific research and environmental management programs, as well as contemplates the first objective of the Global Plant Conservation Strategy, concerning documented and recognized knowledge of the biodiversity of the participating countries (SCBD 2019).

The present study aims to study the Alismataceae flora in Espírito Santo state by preparing taxonomic identification keys, morphological descriptions, illustrations, taxonomic comments, as well as by presenting geographical distribution data and species conservation status.

\section{Materials and Methods}

Herbaria records of specimens from Espírito Santo state were obtained by researching the Splink (CRIA 2011-onwards) and Reflora-Virtual Herbarium (2020) databases. Subsequently, the samples deposited in the CVRD, MBML, R and VIES Herbaria were analyzed. The taxonomic description of the family followed Stevens (2001-onwards). Species were identified based on the taxonomic treatments of Matias (2020), Leithonen (2008) and Haynes \& Hellquist (2000). The morphological terminology agrees with Radford et al. (1974) and habit classification follows Cook (1996). The species conservation status is based on Martinelli \& Moraes (2013). Occurrence maps were generated using data from herbaria, compiled in the QGIS program, version 3.10.0 (QGIS Development Team 2019).

\section{Results and Discussion}

Alismataceae Ventenat

Herbs laticiferous, annual or perennial, glabrous to pubescent, hydrophyte bottom-rooted emergent, erect or floating leaves and stems. Underground system with rhizomes, corms and adventitious roots. Stolons occasionally present. Submerged leaves present or not, phyllodial, linear or elliptic-lanceolate, glabrous, sessile; floating leaves ovate or orbicular, peciolate, sheath with hyaline margin; emerged leaves ovate, elliptic, sagitate, lanceolate, peciolate, secretory pellucid ducts marks in blade present or not, primary veins merging with each other or not, vascular bundles inverted, petiole trigonous or terete, sheath with hyaline margin. Inflorescence cymose, branched, paniculiform or umbelliform; peduncle angulate or terete, erect or decumbent and floating; rachis trigonous or terete, winged or not, bract ovate or elliptic-lanceolate, apex acute, acuminate, rounded, hyaline margin, free or connate at the base; vegetative proliferations occasionally present, stoloniferous or clumped. Flowers monoclinous or diclinous, trimerous, dichlamydeous, cyclic; nectary at base of corolla, androecium, staminodes or carpel flanks; sepals coriaceous, green, cymbiforms, glabrous to pubescent, dorsally ribbed or smooth, reflexed or adpressed persistent and surrounding the fruit; petals membranaceous, ovate, elliptic or obovate, clawed or not, white or pale yellow, occasionally with a yellow or purple spot at the base; stamens 6-many, filament laminar, anther 2-theca, basifixed or versatile, dehiscing by longitudinal slits; carpels 6-many, free in spiral arrangement on conical receptacle or one whorled, uniovulate or pluriovulate. Fruit achene or follicle, surface ribbed or not, glands present or not, apical erect beak. Seeds U-shaped, surface ornamented, embryo strongly curved, U-shaped.

The family is represented by the genera Albidella, Alisma, Astonia, Baldellia, Burnatia, Butomopsis, Caldesia, Damasonium, Echinodorus, Helanthium, Hydrocleys, Limnocharis, Limnophyton, Ranalisma, Sagittaria, Wiesneria (Stevens 2001-onwards; Lethonem \& Myllys 2008; WFO 2019). These genera are distributed on tropical regions but some species occur in temperate regions (Stevens 2001-onwards; WFO 2019). A total of eight species of the genera Echinodorus, Helanthium, Hydrocleys, Limnocharis and Sagittaria have been recorded to Brazil (Matias 2020) and present occurrence records in Espírito Santo state. 


\section{Alismataceae taxa identification key of Espírito Santo}

1. Flowers diclinous.

2. Carpellate flowers with reflexed sepals; achenes 1-glandular

7. Sagittaria lancifolia subsp. lancifolia

2'. Carpellate flowers with adpressed sepals; achenes eglandular..... 8. Sagittaria rhombifolia

1'. Flowers monoclinous.

3. Stamens 6; carpels arranged in a single whorl; receptacle flattened

1. Alisma plantago-aquatica

3'. Stamens 9, 12 or numerous; carpels spirally arranged; receptacle conical.

4. Androecium with basifixed anthers 4. Helanthium bolivianum

4'. Androecium with versatile anthers.

5. Petiole trigonous, aseptate; fruits flattened with longitudinal furrowed

6. Limnocharis flava

5'. Petiole terete, septate; fruits swollen without longitudinal furrowed

5. Hydrocleis nymphoides

6. Blade with secretory pellucid duct marks as points or short lines

2. Echinodorus grandiflorus

6'. Blade without secretory pellucid duct marks

3. Echinodorus macrophyllus

1. Alisma plantago-aquatica L., Sp. Pl. 1: 342. 1753.

Fig. 1a-d, 3

Herb $115-145 \mathrm{~cm}$ tall, perennial, emergent, glabrous. Leaf blade $8-14 \times 3-8 \mathrm{~cm}$, broadly elliptic to ovate, apex acute to acuminate, base cuneate to rounded, campilodromous, 7-9 veins, secretory pellucid duct marks in blade as reticulum; petiole $27-45 \mathrm{~cm}$ long, aseptate; sheath 5-11 $\mathrm{cm}$ long. Inflorescence paniculiform; peduncle 110-150 cm long., terete, aseptate, erect; axis 35-56 long., 2-5 whorls, trigonous, not winged, vegetative proliferation absent; bract $4-25 \mathrm{~mm}$ long., ovate to lanceolate, apex acuminate, base free. Flower monoclinous; pedicel $20-42 \mathrm{~mm}$ long.; sepals ca. $4 \mathrm{~mm}$ long, ovate, ribbed, reflexed; petals obovate, 3-4 mm long., not clawed, white to pale purple; stamens 6 , anther versatile; carpels more than 20, uniovulated, arranged in a single whorl on flattened receptacle. Achene 1.5-2 × $1.5 \mathrm{~mm}$, obovate, not ribbed, eglandular, dorsal canaliculate, beak ca. $0.1 \mathrm{~mm}$ long., erect. Seed 1.

Examined material: Santa Teresa, Mello Leitão Biology Museum Park, 3.II.2000, fl. and fr., V. Demuner \& E. Bausen 712 (EAC, MBML); Santa Lúcia Ecological Station, forest on the right bank of the Timbui river, 12. II.1999, fl., R. Mello-Silva et al. 1556 (EAC, MBML); main trail, 16.IX.2002, fr., R.R. Vervloet et al. 940 (EAC, MBLM).

This exotic species has only been collected in one municipality, probably recently introduced, since records date back to this century. Biogeographic analysis has indicated that Alisma species lived in West Palearctic area and migrated to North America during the Miocene (Chen et al. 2012). Alisma plantago-aquatica populations occur in North America, Africa, Asia, Australia and Europe (Wang et al. 2010), with no previous records found in Brazil. Individuals can be identified by petals purplish pink to lilac, androecium with 6 stamens, gynoecium with carpels arranged in a single whorl on a flattened receptacle and style ca. $1 \mathrm{~mm}$ long. (Fig. 1a-d). This species can resist the desiccation of flooded environments because of its cryptophytic life form and can occupy the same habitats as the other Alismataceae from Espírito Santo state. Thus, populations of this species should be mapped and monitored since records indicate the presence of them in permanent preservation areas.

2. Echinodorus grandiflorus (Cham. \& Schltdl.) Micheli, Monogr. Phan. 3: 57. 1881. Fig. 1e-g, 3

Herb $110 \mathrm{~cm}$ tall, perennial, emergent, glabrescent to pubescent, trichomes stellate. Leaf blade 15-40 × 9-32 cm, sagittate, apex acute to round, base cordate, campilodromous, 13-15 veins, secretory pellucid duct marks in blade as dots or short lines; petiole $34-76 \mathrm{~cm}$ long, aseptate; sheath 8-12 cm long. Inflorescence paniculiform; peduncle $80-110 \mathrm{~cm}$ long., trigonous, aseptate, erect; axis $27-55 \mathrm{~cm}$ long, 7-11 whorls, trigonous, not winged, vegetative proliferation present, clumped; bract 6-33 mm long., lanceolate, apex acute, base free. Flower monoclinous; pedicel 

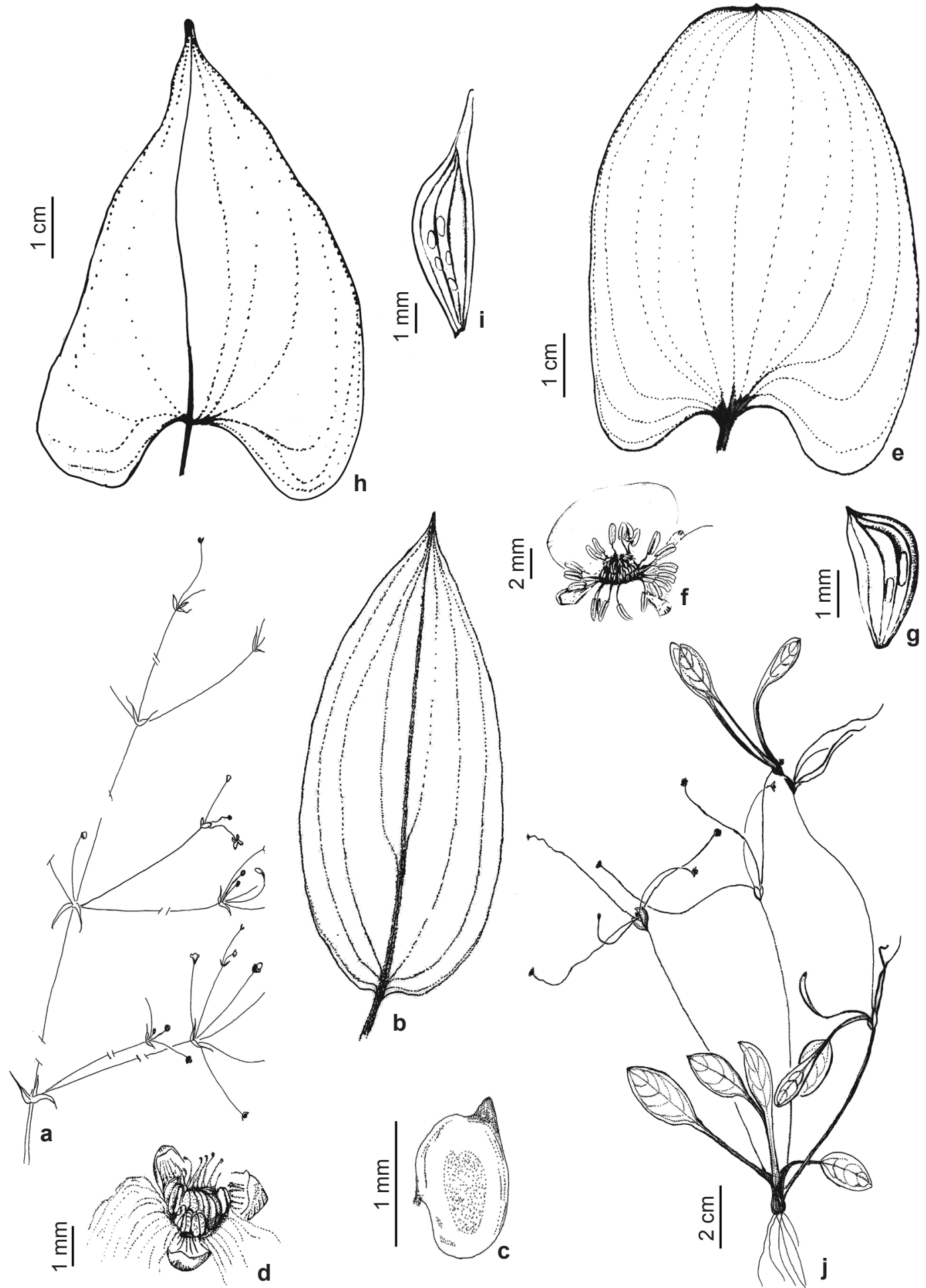

Figure 1 -a-d. Alisma plantago-aquatica - a. inflorescence; b. leaf; c. fruit; d. flower. e-g. Echinodorus grandiflorus - e. leaf; f. flower; g. fruit. h-i. Echinodorus macrophyllus - h. leaf; i. fruit. j. Helanthium bolivianus - habit. (a-c. Mello-Silva et al. 1556; d. Demuner \& Bausen 712; e-f. Vervloet et al. 1514; g. Magnago 715; h-i. D.M. Dias et al. 44; j. D.A. Folli 3919.). 
12-18 mm long; sepal 3-5 mm long, ovate, ribbed, reflexed; petal ca. $20 \mathrm{~mm}$ long, ovate, not clawed, white; stamens more than 20, anther versatile; carpels more than 40, uniovulate, spirally arranged on conical receptacle. Achene 2.5-3 × 1.2-1.8 $\mathrm{mm}$, obovate, 1-2 ribbed, 2-3 glandular, gland oblong lenticular, conspicuos, beak $0.2-0.3 \mathrm{~mm}$ long. Seed 1.

Examined material: Governador Lindemberg, Alto Moacir, propr. Vitório Salomão, fr., 21.II.2006, L.F.S. Magnago et al. 715 (MBML). Santa Teresa, Alto Piaba, fl. and fr., 14.VIII.1984, R.M. Piziolo 223 (EAC, MBML); Mello Leitão Biology Museum Park, fr., 3.II.2000, V. Demuner \& E. Bausen 711 (EAC, MBML); Santo Henrique, entrance of Valdecir Freire's property, fr., 11.III.2005, A.P. Fontana et. al. 1132 (MBML). Nova Lombardia, Augusto Ruschi Biological Reserve, road from the Casa da Pedra, fl., 11.XII.2002, R.R. Vervloet et al. 1514 (EAC, MBML); Nova Lombardia Biological Reserve, road from Nova Lombardia, fl. and fr., 20.II.2002, L. Kollmann et al. 5605 (MBML). Venda Nova do Imigrante, Incaper Experimental Farm, fl. and fr., 2011, L.B.M Baptista (VIES 26206).

This species holds the highest collection records numbers for the state, including those made in conservation units. Populations occur from Central America to northern Argentina (Haynes \& Holm-Nielsen 1994) and colonize wetlands in all regions of Brazil (Matias 2020). Individuals can be identified by robust clumps, some reaching $4 \mathrm{~m}$ in height (Matias 2007), with very wide leaves, sagittate, occupying periodically flooded floodplains. Echinodorus grandiflorus was recognized as a medicinal species by the Brazilian Pharmacopoeia (2019) and is also known as "chapéu-de-couro" like E. macrophyllus. However, E. grandiflorus differs from E. macrophyllus by presenting pellucid marks visible to the naked eye as dots or short lines on the blade, in addition to different phytochemical compounds (Dias et al. 2013). The species' populations occur in different regions in Espírito Santo state, including preserved areas. The species has not been placed on the Red List of Brazil (Martinelli \& Moraes 2013).

\section{Echinodorus macrophyllus (Kunth) Micheli,} Monogr. Phan. 3: 50. 1881. Fig. 1h-i, 3

Herb 30-200 cm tall, perennial, emergent, glabrescent to pubescent, trichome stellate. Leaf balde $7-21 \times 6-13 \mathrm{~cm}$, sagittate, apex atenuate to acute, base cordate, campilodromous, 9-11 veins, secretory pellucid duct marks in blade absent; petiole 21-26 cm long, aseptate; sheath 6-10 $\mathrm{cm}$ long. Inflorescence paniculiform; peduncle
18-45 cm long., terete, aseptate, erect; axis 15-18 cm long., 7-8 whorls, trigonous, not winged, vegetative proliferating present, clumped; bract 15-20 mm long, lanceolate, apex acute, base free. Flower monoclinous; pedicel 10-15 mm long., sepal 3-6 mm long., ovate, ribbed, reflexed; petal 15-25 mm long., ovate, not clawed, white; stamens above 20, anther versatile; carpels more than 30 , uniovulate, spirally arranged on conical receptacle. Achene 4-5 × $3.5 \mathrm{~mm}$, oblanceolate, 3-4 ribbed, 5-7 glandular, gland lenticular, conspicuous, beak 1-1.5 mm long., erect. Seed 1.

Examined material: Cachoeiro de Itapemirim, Pacotuba, quilombola community of Monte Alegre, fr., 4.XI.2013, D.M. Dias et al. 44 (VIES). Mantenópolis, Santa Luzia road in Mantenópolis, banks of the São Francisco River, 9.IV.2018, fl. and fr., A.M. Assis \& R.S. Cribari 4462 (VIES). Vitória, CVRD areas, artificial ponds, 15.VIII.2007, O.J. Pereira \& G. Lübe 7498 (EAC, VIES).

The species has been collected occasionally in the state, from the lowland coast to the east of Serra do Caparaó. Populations occur from Central America to southern Brazil (Haynes \& Holm-Nielsen 1994) and are widely distributed in wetlands in all regions of Brazil (Matias 2020). Populations can be identified by robust clumps, reaching up to $2 \mathrm{~m}$ tall (Haynes \& Holm-Nielsen 1994), with sagittate leaves in periodically flooded floodplains. In the interior of Brazil, $E$. macrophyllus is traditionally recognized as a medicinal plant (Lorenzi \& Matos 2002), with leaves that have terpenoids with therapeutic value (Kobayashi et al. 2000). However, both $E$. macrophyllus and E. grandiflorus are popularly called "chapéu-de-couro" (Panizza 1997), but E. macrophyllus does not have pellucid marks on blade, a striking feature that differentiates it from E. grandiflorus. In addition, its fruits have a larger beak (Fig. 1i), prominent in the achenecetum. The species has not been added to the Red List of Brazil (Martinelli \& Moraes 2013).

4. Helanthium bolivianum (Rusby) Lehtonen \& Myllys. Cladistics 24: 228. $2008 . \quad$ Fig. 1j, Herb 10-22 cm tall, annual, emergent, glabrous. Leaf blade $1.5-4 \times 0.7-1.5 \mathrm{~cm}$, oblong to elliptic, apex obtuse to acute, base rounded to attenuate, acrodromous, 3 veins, secretory pellucid duct marks in the blade as polygonal reticula; petiole $3-9 \mathrm{~cm}$ long., aseptate; sheath 5-8 cm long. Inflorescence umbelliform; peduncle ca. $9 \mathrm{~cm}$ long., terete, aseptate, erect or floating; axis inconspicuous, not winged, vegetative 
proliferations present, stoloniferous; bract $3-5 \mathrm{~mm}$ long., lanceolate, apex acuminate, connate at the base. Flower monoclinous, pedicel 3-7 cm long., sepal elliptic, 3-5 mm long., ribbed, reflexed; petal ca. $6 \times 4 \mathrm{~mm}$, clawed, white; stamens 9 , anther basifixed; carpels 18-20, uniovulate, spirally arranged on conical receptacle. Achene ca. $1.5 \times$ $1 \mathrm{~mm}$, obovate, 3-4 ribbed, eglandular, beak ca. $0.4 \mathrm{~mm}$ long., lateral. Seed 1 .

Examined material: Linhares, CVRD Nature Reserve, Aceiro Street with Spelta, $0.1 \mathrm{~km}$, fl. and fr., 7.V.2001, D.A. Folli 3919 (R); Orelha de Macaco street, 0.4 km, fl. and fr., 31.X.200, D.A. Folli 3731 (R).

The species has only been recorded in the Vale Natural Reserve, municipality of Linhares. However, as populations occur from the northeast of the United states to the south of South America (Haynes \& Holm-Nielsen 1994) and are widely spread in wetlands of Brazil (Matias 2020), such restricted distribution profile may be underestimated for Espírito Santo state. Populations can be identified by the miniature clumps formed by elliptical leaves, with slender stems supporting umbelliform inflorescences with white flowers. The species is terophytic, resisting desiccation caused by seasonality in its seed stage, and is commonly found in periodically flooded floodplains. The species has not been added to the Red List of Brazil (Martinelli \& Moraes 2013).

5. Hydrocleys nymphoides (Willd.) Buchenau, Index Crit. Butom. Alism. Juncag: 9. 1868.

Fig. 2a-b, 4

Herb ca. $50 \mathrm{~cm}$ tall, perennial, emergent with floating leaves and stems, stoloniferous, glabrous; stolons ca. $10 \mathrm{~cm}$ long, septate. Leaf blade 3-5 $\times 2.5-4.5 \mathrm{~cm}$, oval to orbicular, apex round to slightly emarginated, base round to truncate, acrodromous, 7 veins, secretory pellucid duct marks in blade absent; petiole 6-13 cm long., terete, septate; sheath ca. 2-2.5 cm long. Inflorescence umbelliform; peduncle 7-13 cm long., terete, septate, floating, vegetative proliferation present, stoloniferous; bract ca. $25 \mathrm{~mm}$ long., elliptic to lanceolate, apex acute, base free. Flower monoclinous; pedicel 25-30 mm long.; sepal 15-25 $\mathrm{mm}$ long., elliptic to ovate, not ribbed, adpressed; petal 25-35 mm long., broadly ovate, pale yellow occasionally with a yellow spot at the base; stamens more than 20 , in two or more series, the outer composed of staminodia, anther basifixed; carpels 6-8, pluriovulated, spirally arranged on conical receptacle. Follicle ca. $15 \times 4 \mathrm{~mm}$, lanceolate, not ribbed, eglandular, beak ca. $4 \mathrm{~mm}$ long., erect. Seeds numerous.

Examined material: Conceição da Barra, Itaúnas River, 15.VII.1991, fl., P.C. Vinha 1246 (EAC, VIES); Itaúnas State Park, Itaúnas River, 25.VIII.2002, fl., O.J. Pereira et al. 7000 (EAC, VIES). Linhares, Ponta do Ipiranga, 2-3 km to the north, 15.X.1992, fl., G. Hatschbach 58097 (MBML); CVRD Natural Reserve, Constantly flooded floodplain, 3.V.2001, fl., D.A. Folli 3913 (CVRD, R). Santa Luzia, Águia Branca, 21.XII.2007, fl., V. Demuner et al. 4873 (MBML). Santa Teresa, Santa Lúcia Biological Station, floodzone of the Timbuí river, 18.VII.2002, fl., C.P. Bove 1063 (CVRD, R)

The species presents few and records concentrated in preserved areas and represents a new record to Espírito Santo state. However, its populations are distributed throughout South America, being the most common species of the genus (Haynes \& Holm-Nielsen 1992) and presenting a wide occurrence in wetlands of Brazil (Matias 2020). Populations can be identified by flexible floating stems with the membranaceous circular leaves and inflorescences at the water surface. In addition, the yellowish, showy flowers have cymbiform green sepals without distinction of the central vein and the seeds occasionally have a surface with glandular trichomes (Haynes \& Holm-Nielsen 1992). The species is cryptophytic, resisting desiccation caused by rainfall seasonality due to the presence of rhizomes, and is commonly found in periodically flooded floodplains. The species has not been added to the Red List of Brazil (Martinelli \& Moraes 2013).

6. Limnocharis flava (L.) Buchenau. Index Crit. Butom. Alism. Juncag: 13. $1868 . \quad$ Fig. 2c-d, 4 Herb 90-110 cm tall, perennial, emergent. Leaf blade 25-28 × 17-19 cm, oval, apex round to slightly emarginated, base round to truncate, acrodromous, 15-17 veins, secretory pellucid duct marks in blade absent; petiole $64-70 \mathrm{~cm}$ long., trigonous, aseptate; sheath ca. $12 \mathrm{~cm}$ long. Inflorescence umbelliform; peduncle $102-110 \mathrm{~cm}$ long., terete, aseptate, erect, vegetative proliferation occasionally present, clumped; bract $15-45 \mathrm{~mm}$ long., elliptic to lanceote, apex acute, base free. Flower monoclinous; pedicel ca. $60 \mathrm{~mm}$ long.; sepal ca. $30 \mathrm{~mm}$ long., elliptic to ovate, not ribbed, adpressed; petal $32-36 \mathrm{~cm}$ long., broadly ovate, pale yellow occasionally with a yellow spot at the base; stamens more than 20, in two or more series, the outer staminodium, anther basifixed; carpels more than 10 , pluriovulated, spirally arranged on conical receptacle. Follicle non vidi. Seeds non vidi. 
Examined material: Linhares, 14.VI.2011, fl., D.A. Folli 6783 (CVRD); CVRD Natural Reserve, João Pedro River, 20.IX.2004, f1., D.A. Folli 4936 (CVRD).

The species has only been recorded once in the state, probably evidencing a subsampling of populations. This is because the species has wide distribution in the Neotropical region, from northwestern Mexico to northern Argentina and eastern Brazil (Haynes \& Holm-Nielsen 1992). In Brazil, the species occurs in all regions (Matias 2020).
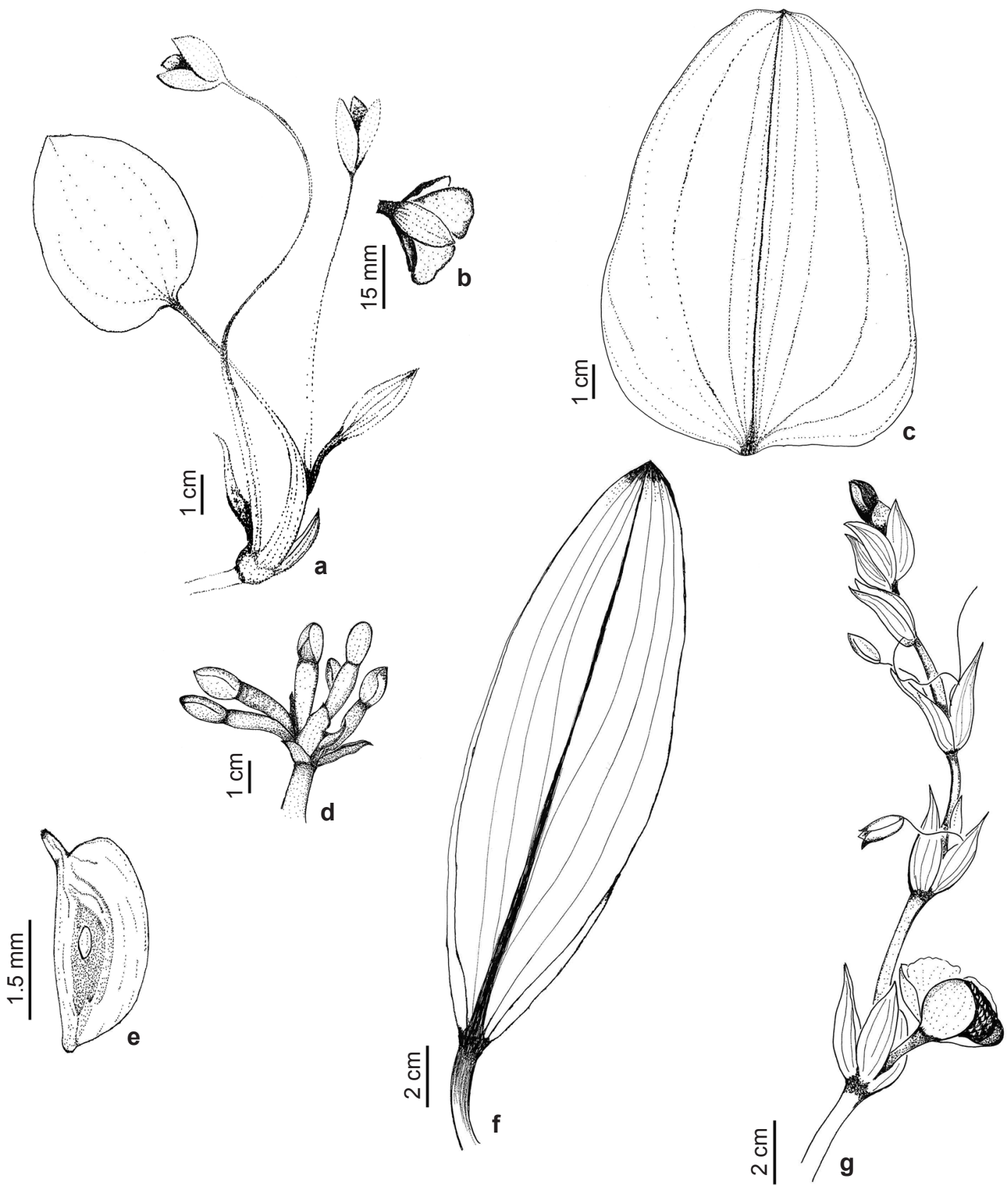

Figure 2 - a-b. Hydrocleis nymphoides - a. apex of stem, with leaf and flower buds; b. flower showing the sepal without main vein. c-d. Limnocharis flava - c. leaf blade; d. apex of inflorescence. e. Sagittaria lancifolia subsp. lancifolia - fruit; f-g. Sagittaria rhombifolia - f. leaf; g. inflorescence. [a. D.A. Folli 3913; b. C.P. Bove et al. 1063; c-d. D.A. Folli 4936; e. O.J. Pereira 2133; f-g. Kosten \& Lacerot (R 218765)]. 
The species is easily recognized by its long vertical stems, projecting the umbelliform inflorescences above the leaves, with yellow flowers supported by dilated pedicels. The species is cryptophytic and able to resist seasonality by the presence of rhizomes, but collection records indicate constantly flooded habitats for this species. The species has not been added to the Red List of Brazil (Martinelli \& Moraes 2013).

7. Sagittaria lancifolia L. subsp. lancifolia, Syst. Nat. ed.10, 2: 1270. 1759. Reference illustration from Matias \& Irgang (2006) p. 184 . Fig. 2e, 4 Herb $112-120 \mathrm{~cm}$ tall, perennial, glabrous, emergent. Leaf blades 13-22 × 2.5-5.6 cm, elliptic, apex acute, base cuneate, acrodromous, 5-7 veined, secretory pellucid duct marks in blade absent; petiole 20-58 cm long., aseptate; sheath $10-18 \mathrm{~cm}$ long. Inflorescence paniculate, staminate flowers above and carpellate below; peduncle 45-120 cm long., trigonous, aseptate, erect; axis 25-38 cm long., 5-9 whorls, trigonous, not winged, vegetative proliferation absent; staminate bract ca. $15 \mathrm{~mm}$ long., ovate, not ribbed, apex acute, base free; carpellate bract ca. $2 \mathrm{~mm}$ long, ovate, apex

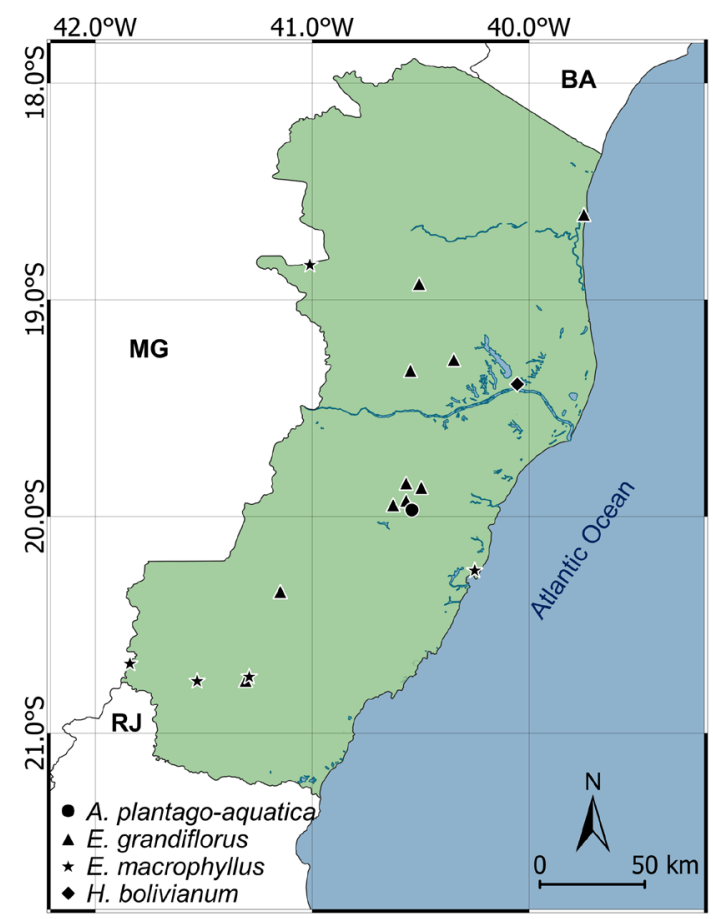

Figure 3 - Geographic distribution map of Alisma, Echinodorus and Helanthium species in Espírito Santo state. acute, base free. Flower diclinous; staminate flower pedicel ca. $15 \mathrm{~mm}$ long.; sepal ca. $10 \mathrm{~mm}$ long. ovate, not ribbed, reflexed; petals ca. $15 \mathrm{~mm}$ long., ovate, clawed, white; stamens more than 20 , anther basifixed; whorl of sterile carpels absent; carpellate flower pedicel 10-12 mm long.; sepals 15-20 mm long, ovate, not ribbed, reflexed; petal $20-25 \mathrm{~mm}$ long., broadly ovate, clawed, white; carpels more than 30 , uniovulated, spirally arranged on conical receptacle; a whorl of stamina rarely present. Achenes ca. $3 \mathrm{~mm} \times 1 \mathrm{~mm}$, obovate, not ribbed, 1-glandular, gland oblong lenticular, beak ca. 0.5 mm long., erect. Seed 1.

Examined material: Guarapari, Paulo Cesar Vinha State Park, herbaceous swamp, $20.5974^{\circ} \mathrm{S}, 40.4115^{\circ} \mathrm{W}$, 20.IX.2006, fl. and fr., R.T. Valadares 276 (VIES); restinga, 26.VII.1990, fr., O.J. Pereira 2133 (EAC, VIES); Setiba, herbaceous swamp in restinga, 18.III.1989, fr., O.J. Pereira 1943 (VIES). Vila Velha, Interlagos, Morada do Sul, herbaceous swamp, 5.IV.2008, fl. and fr., F.B.C. Souza et al. 133 (EAC, VIES).

The sampled populations occurred in the coastal region of Espírito Santo state, as well as in coastal regions throughout the American continent (Bogin 1955; Keener 2005). The species is

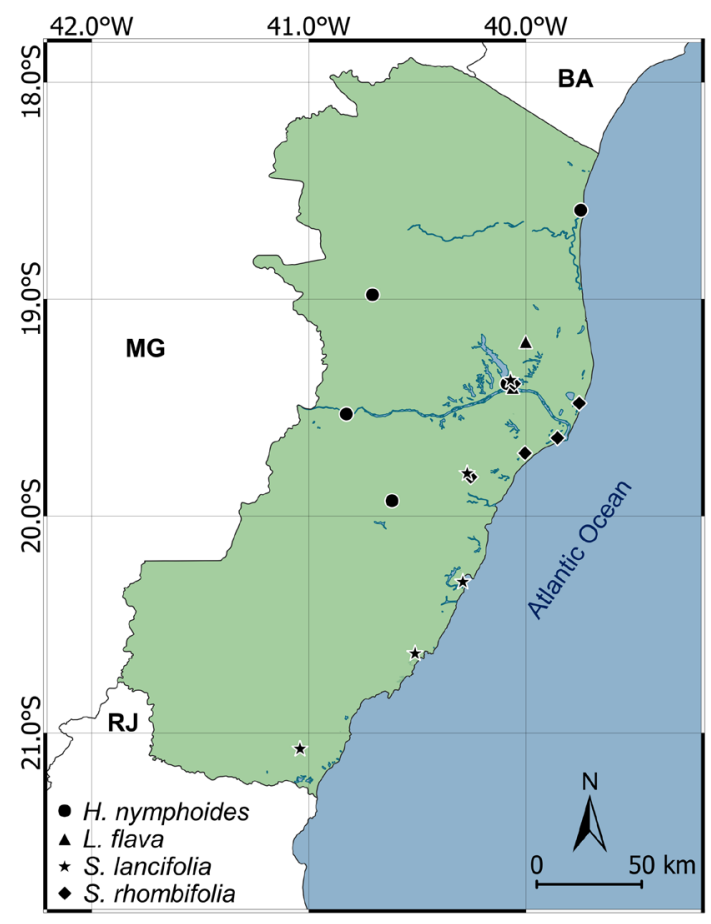

Figure 4-Geographic distribution map of Hydrocleis, Limnocharis and Sagittaria species in Espírito Santo state. 
cryptophytic and tends to occupy the flooded areas of restingas, where $S$. rhombifolia also occurs. However, the leaves of $S$. lancifolia are much narrower and its inflorescences are more delicate. Narrow-lanceolate leaves prevailed in the sampled populations of Espírito Santo, as well as in Brazil (Matias \& Irgang 2006), which is a characteristic that should not be considered for infraspecific determination, since morphological plasticity of S. lancifolia leaves is related to phosphorus content of the substrate (Richards \& Ivey 2004). However, phylogenetic analysis confirmed the infraspecific classification proposed by Bogin (1955), with South American populations of Sagittaria lancifolia subsp. lancifolia characterized by nodal bracts striate to ribbed (Keener 2005).

8. Sagittaria rhombifolia Cham., Linnaea 10: 219. 1835. Reference illustration from Matias \& Irgang (2006) p. 186.

Fig. 2f-g

Herb 60-80 cm tall, perennial, emergent, glabrous. Leaf blade 16-24 × 4-9 cm, rhomboid, apex acute, base attenuate, acrodromous, 7-11 veined, secretory pellucid duct marks in blade absent; petiole 25-60 cm long., aseptate; sheath 7-9 cm long. Inflorescence paniculate, staminate flowers above and carpellate below; peduncle 20$53 \mathrm{~cm}$ long., terete, aseptate, erect; axis ca. $20 \mathrm{~cm}$ long., 5-7 whorls, terete, not winged, vegetative proliferation absent; staminate bract 25-40 mm long, lanceolate, apex acute, base connate; carpellate bract 35-40 mm long., lanceolate, apex acute, base connate. Flowers diclinous; staminate flower pedicel 45-92 mm long.; sepal 10-15 mm long., ovate, not ribbed, adpressed; petal ovate, 10-21 mm long., clawed, white; stamens more than 30 , anther basifixed; whorl of sterile carpels absent; carpellate flowers pedicels 25-62 mm long.; sepals 15-19 mm long., ovate, adpressed; petal 14-28 mm long., ovate, clawed, white; carpels more than 30, uniovulated, spirally arranged on conical receptacle; whorl of staminodia present. Achenes $7-8 \times 2-3 \mathrm{~mm}$, obovate, not ribbed, eglandular, beak 1-1.5 mm long. Seed 1.

Examined material: Lagoa doutor, -39.772 lat., 19.4806 long., 9.IX.2005, S. Kosten \& G. Lacerot (218765 R); Lagoa das Cacimbas, -39.8749 lat., -39.6472 long., 30.VIII.2005, S. Kosten \& G. Lacerot (218764 R). Aracruz, Brejo Grande, restinga, 27.X, fl., O.J. Pereira 3984 (EAC, VIES); Vila do Riacho, banks of the Riacho chanel, 8.VIII.2012, fl., A.M. Assis \& J. Santos 3332 (VIES). Linhares, Areal, herbaceous swamp in restinga, 14.XI.1991, fl., O.P. Pereira 2460 (VIES, HUEFS, R);
Degredo, restinga, 14.XII.2011, O.J. Pereira \& A.G. Oliveira 7947 (VIES).

The sampled populations only occurred in the eastern region of Espírito Santo state, but the species is widely distributed in Brazil (Matias 2020), with records in the low-lying regions of South America (Bogin 1955). The species is cryptophytic and tends to occupy permanent seasonal environments, occurring in Espírito Santo state in flooded areas of restinga. The coastal environments are also occupied by S. lancifolia subsp. lancifolia, but $S$. rhombifolia differs from this by presenting more robust inflorescences, with thicker stems, large bracts and wider flowers. Rhomboid leaves prevailed in the sampled populations of Espírito Santo, but more oval and lanceolate forms are common in the South and Northeast region, respectively (Matias 2006). The species has not been added to the Red List of Brazil (Martinelli \& Moraes 2013).

\section{References}

Bogin C (1955) Revision of the genus Sagittaria (Alismataceae). Memoirs of the New York Botanical Garden 9: 179-233.

Brazilian Pharmacopoeia (2019) Agência Nacional de Vigilância Sanitária, Brasília. 6 $6^{\mathrm{a}}$ ed. Vol. 1 e 2. Available at <https://pfarma.com.br/blog/4344farmacopeia-brasileira-6-edicao.html $>$. Access on 4 February 2020.

Canalli YM \& Bove CP (2017) Flora do Rio de Janeiro: Alismataceae. Rodriguésia 68: 17-28.

Chen LY, Chena JM, Gituru RW, Temame TD \& Wang QF (2012) Generic phylogeny and historical biogeography of Alismataceae, inferred from multiple DNA sequences. Molecular Phylogenetics and Evolution 63: 407-416.

Cook DK (1996) Aquatic plant book. SPB, Amsterdam. $228 \mathrm{p}$.

CRIA - Centro de Referência e Informação Ambiental (2011) Specieslink. Available at $<$ http://www.splink. org.br/index>. Access on 2 October 2019.

Dias EGE, Valenzuela VCT, Alves MR, Duarte MGR \& Garcia EF (2013) Qualidade e autenticidade de folhas de chapéu-de-couro (Echinodorus grandiflorus) oriundas de fornecedores de São Paulo. Revista Brasileira de plantas medicinais 15: 250-256.

Garbin ML, Saiter ZF, Carrijo TT \& Peixoto AL (2017) Breve histórico e classificação da vegetação capixaba. Rodriguésia 68: 1883-1894.

Haynes RH \& Holm-Nielsen L (1992) The Limnocharitaceae. Flora Neotropica 56: 1-32

Haynes RH \& Holm-Nielsen L (1994) The Alismataceae. Flora Neotropica 64: 1-112. 
Haynes RH \& Hellquist CB (2000) Alismataceae. Flora of North America North of Mexico, Provisional Publication. Flora of North America Association. Available at $<$ http://www.efloras.org/florataxon. aspx $>$. Access on 4 February 2020.

Jordy Filho A (1987) Vegetação: as regiões fitoecológicas, sua natureza e seus recursos econômicos. Estudo fitogeográfico. In: IBGE. Folha SE. 24 Rio Doce: geologia, geomorfologia, pedologia, vegetação e uso potencial da terra. Fundação Instituto Brasileiro de Geografia e Estatística, Rio de Janeiro. Pp. 553-624.

Keener BR (2005) Molecular systematic and revision of the aquatic Monocot genus Sagittaria (Alismataceae). Ph.D. Thesis. The University of Alabama, Tuscaloosa. 168 p.

Kobayashi J, Sekiguchi M, Shigemori H \& Ohsaki A (2000) Echinophyllins A and B, novel nitrogencontaining clerodane diterpenoids from Echinodorus macrophyllus. Tetraedron letters 41: 2939-2943.

Lehtonen S \& Myllys L (2008) Cladistic analysis of Echinodorus (Alismataceae): simultaneous analysis of molecular and morphological data. Cladistics 24: 218-239.

Lorenzi H \& Matos FJA (2002) Plantas medicinais no Brasil: nativas e exóticas cultivadas. Instituto Plantarum, Nova Odessa. 544p.

Martinelli G \& Moraes MA (2013) Livro Vermelho da Flora do Brasil. Instituto de Pesquisas Jardim Botânico do Rio de Janeiro, Rio de Janeiro. 1100p.

Matias LQ \& Irgang BE (2006) Taxonomy and distribution of Sagittaria (Alismataceae) in north-eastern Brazil. Aquatic Botany 84: 183-190.

Matias LQ (2007) O gênero Echinodorus (Alismataceae) no domínio da Caatinga brasileira. Rodriguésia 58: 743-774.

Matias LQ, Barros FSM, Santos filho, LAF \& Messina T (2013) Alismataceae. In: Martinelli G \& Moraes MA (orgs.) Livro Vermelho da Flora do Brasil. Instituto de Pesquisas Jardim Botânico do Rio de Janeiro, Rio de Janeiro. 115p.
Matias LQ \& Souza DJL (2011) Alismataceae no estado do Ceará. Rodriguésia 62: 887-900.

Matias LQ (2020) Alismataceae in Flora do Brasil 2020 em construção. Instituto de Pesquisas Jardim Botânico do Rio de Janeiro. Available at <http:// reflora.jbrj.gov.br/reflora/floradobrasil/FB39>. Access on 3 August 2020.

Panizza S (1997) Plantas que curam: cheiro de mato. $28^{\mathrm{a}}$ ed. IBRASA, São Paulo. 279p.

QGIS Development Team (2019) QGIS Geographic Information System. Ver. 3.10.0. Open Source Geospatial Foundation Project. Available at $<$ http:// qgis.osgeo.org $>$. Access on 14 February 2020.

Reflora - Herbário Virtual (2020) Available at <http:// reflora.jbrj.gov.br/reflora/herbarioVirtual/>. Access on 4 February 2020.

Richards JH \& Ivey CT (2004) Morphological plasticity of Sagittaria lancifolia in response to phosphorus. Aquatic Botany 8: 53-67.

SCBD - Secretariat of the Convention on Biological Diversity (2019) Global Strategy Objectives. Available at $<$ https://www.cbd.int/gspc/objectives. shtml $>$. Access on 14 november 2019.

Souza WO, Pena NTL, Garbin ML \& Alves-Araújo A (2017) Macrófitas aquáticas do Parque Estadual de Itaúnas, Espírito Santo, Brasil. Rodriguésia 68: 1907-1919.

Stevens PF (2001-onwards) Angiosperm Phylogeny Website. Version 14, July. Available at $<$ http://www. mobot.org/MOBOT/research/APweb $>$. Access on 15 November 2019.

Valadares RT, Souza FBC, Castro NGD, Peres ALSS, Schneider SZ \& Martins MLL (2011) Levantamento florístico de um brejo-herbáceo localizado na restinga de Morada do Sol, município de Vila Velha, Espírito Santo, Brasil. Rodriguésia 62: 827-834.

Wang QF, Haynes RR \& Hellquist CB (2010) Flora of China 23: 87-88.

WFO (2019) World Flora Online. Available at <http:// www.worldfloraonline.org $>$. Access on 13 November 2019.

\section{List of exsiccates}

Almeida TE 726(5). Assis AM \& Cribari RS 4462(3). Assis AM \& Santos J 3332(8). Baptista LBM VIES 26206(2). Boone W 616(5). Bove CP et al. 1063(5). Demuner V \& Bausen E 712(1), 711(2). Demuner V et al. 977(5), 4873(5). Dias DM et al. 44(3). Ferreira JM 13(2). Folli DA 3731(4), 3919(4), 3856(5), 3913(5), 4936(6), 6783(6), 1746(7), 2386(7), 2433(7), 2460(7), 4558(7). Fontana AP et al. 1132(2). Goes MB \& Barros EM 215(2). Hatschbach G 58097(5). Kollmann L \& Esgario C 10086(5). Kollmann L et al. 5605(2). Kosten S \& Lacerot G R 218764(8), R 218765(8). Magnago LFS et al. 715(2). Mello-Silva R et al. 1556(1). Nina Silva 483(3). Pedralli G \& Silva 2648(2). Pereira OJ 1943(7), 2133(7), 2460(8), 3984(8). Pereira OJ \& Giaretta AO 7947(8). Pereira OJ \& Lübe G 7498(3). Pereira OJ et al. 7000(5). Piziolo RM 223(2). Simões JM et al. 35(2). Soares ME BHZB 1490(3). Souza FBC et al. 133(7). Valadares RT 276(7). Vervloet RR et al. 940(1), 1514(2). Vinha PC 1246(5). 